\title{
The Child David: \\ An Attempt to Understand and Guide \\ Him Through His "Difficultness"
}

Jane K. Adan

University of California

That comparisons are odious is something Cervantes' Don Quixote said to me years ago, and so, at one time or another, say most children I have met, children who, when they are in agreement with Don Quixote, sometimes find themselves in disagreement with the world at large. Take David, for instance. He is seven years old. And he is angry because the adults in charge of a picnic have ruled in favor of another child. Specifically, and please prepare to exercise your adult patience in the face of a child crisis, they have permitted eight-yearold Mark to transform a traditional hamburger into a sort of hamburger/hot dog hybrid; they have let Mark eat a rectangular hamburger patty on a rectangular French roll, instead of a round hamburger patty on a round Kaiser roll, or a typically shaped hot dog on a rectangular French roll, the latter two choices being the only ones David deems appropriate. ${ }^{1}$

Furthermore, David is going to stay angry. In fact, before the afternoon is over, he will find himself cast out socially as, among other things, an unreasonable and unimaginative child whereas Mark will find himself embraced as both reasonable and imaginative. As responsible adults in charge of children, we must ask ourselves what could motivate David, a child who loves picnics as much as any other child, to spoil his own good time and threaten the prevailing harmony of the outing. Why would a child of seven go to such lengths to align himself with Don Quixote, expecially over a comparison as inconsequential as that between a hot dog and a hamburger? In short, what makes David such an uncooperative, difficult child?

\section{David's Situatedness}

Perhaps a partial answer can be found in the specifics surrounding David's anger, in other words, in David's particular situatedness. Background information includes the fact that David's family is hosting the picnic and that they originally intended the rectangular rolls for the hot dogs and the round ones for the hamburgers, mainly because that is the way they eat hamburgers and hot dogs at home. On the other hand, Mark has a home history of eating hamburgers on rectangular French rolls and in addition may not be too concerned about rolls for hot dogs because he doesn't like hot dogs in the first place. As for the actual crisis, it emerges as the two boys 
first notice that the picnic table has been spread with food and as they, deciding to take a closer look, interrupt their play, walk over to the table, admire the food, discuss their range of choices, and make tentative selections toward the contents of a plate that will eventually become their picnic lunch.

But before describing the crisis itself, I want to rephrase the last sentence in the preceding paragraph, substituting for the italicized vocabulary, which is pretty much a part of everyday conversational English, the more specialized vocabulary I might be exposed to as a student of human learning in the tradition of E. Straus (1963), vocabulary I will also italicize. Thus the last sentence in the preceding paragraph would become: As for the actual crisis, it emerges as the two boys sense that the picnic table has been spread with food and as they, deciding to attend to the food, interrupt their play, walk over to the table, perceive the food globally, analyze their range of choices, and begin to synthesize the contents of a plate that will eventually become their picnic lunch.

My aim in rephrasing is to remind myself, before I go on to describe the emerging conflict between David and Mark, of some things that I, as an all too frequently self-absorbed adult, often forget, which are: first, that children exist in the world at large, including the world of home and not just in the world of school, essentially as learners; second, that the home world is, in fact, the child's original, primary, "schoolhouse"; and, finally, that I, as an adult present with the child in the home world, have an obligation to guide the childlearner as the need arises and insofar as I am humanly capable of doing so. ${ }^{2}$

Now on to the emerging conflict between David and Mark, which is probably best revealed through their conversation over the picnic table:

David: There's hamburgers-I helped make them-and hot dogs, potato chips, macaroni salad, Mountain Dew-I told Mom to buy it because you and me like it best-and Pepsi Cola, iced tea, and beer and wine for the grown-ups. For dessert, we made a chocolate cake. I don't like the frosting, but Mom says I can peel it off. For lunch I'm having a hamburger, chips, and Mountain Dew. Laura [David's sister] wants a hot dog. She doesn't eat hamburgers. Not ever. She thinks they're sickening. And we got the kind of rolls Laura likes. For the hot dogs. French ones that are kind of like big hot dog buns. But I'm not having a hot dog. Even though I like them. I'm having a hamburger.

Mark: I'm having a hamburger, too. On one of those French rolls Laura likes. And Mountain Dew. And chips. And salad.

David: No Mark. You can't have a French roll for a hamburger. It wouldn't fit right. They're for hot dogs.

Mark: But I like hamburgers on French rolls. I always eat them like that at home. 
David: It doesn't matter. You still can't have one. They're for the hot dogs. If you want a hamburger, you have to have a round roll.

Mark: But I don't like this kind of round roll. I've never had it before. And they look funny on top. I like the French rolls that Laura likes.

David: Then have a hot dog. They're good. I have them sometimes.

Mark: I don't want to. I don't like them.

David: Then have a hamburger on a round roll.

Mark: I told you David. I don't like round rolls. Don't you listen?

David: Yes I listen. And you do too like round rolls.

Mark: I do not. So don't say I do.

David: You eat round rolls at Burger King [Mark's favorite fast food restaurant].

Mark: That's different David. They only have round rolls at Burger King.

David: Well, that's the only kind we have, too, for hamburgers. See-the hamburgers are all wrapped up on that platter. I helped make them. And they're round. So you have to have a round roll if you want a hamburger. Or the hamburger won't fit.

Mark: I don't care what you say. You're not the boss. I'm going to ask my mother if I can have the roll I want.

David: Go ahead. Ask her. And I'll ask my mother not to let you have one. ${ }^{3}$

Although the conversation and the emerging conflict could be interpreted from many different angles, and although I do not believe it would ever be possible to exhaust all that such a conversation has to say to us, even from one of those angles, I do want to interpret the conversation from my perspective as an adult interested in understanding, rather than in censoring, David: First, David seems proud to be part of the hosting family. For example, he elaborately catalogues the food, and he carefully points out his and his family's attempts to anticipate the needs of others. He refers to the problem of shape repeatedly, and he also mentions that he himself has helped shape the hamburger patties, the first mention as evidence that he has exerted himself in preparing for the guests, in other words, the first as evidence that he is a child moving toward an increasingly adult sense of responsible participation in his world, and the second mention as an attempt to get Mark to finally recognize that the roundness of the hamburger makes it critical that it be eaten on a round roll. David also intends to "synthesize" a meal that exactly suits his tastes (hamburger on a round roll, his favorite soft drink, and chocolate cake with the frosting peeled off).

In general, then, David seems to want to host or direct the picnic according to some plan he has been developing, perhaps through dialogue with himself as well as with his family, a plan that is tied to the 
concrete preparations for the picnic, but which David has personalized to some extent through his imagination. In his role of host, David might be compared to a composer working out a variation on the well-known picnic theme, or perhaps to the director of a play who is turning over from various angles how best to realize the essentials of a given script. And at this point in his directorship, he is perhaps not particularly innovative; he would likely costume Hamlet in gear that reflects the dress of Elizabethan England or the Denmark of Hamlet's setting and would probably object to any flexibility of direction that would dress Hamlet, say, as a 20th century business executive, or, more outrageously still, given David's traditional point of view, send Hamlet on stage nude.

Regardless of the degree of David's innovativeness, however, his pleasure in the picnic does seem clearly tied to his power as a host to please his guests, while at the same time actualizing his own image of what this particular picnic should be. And I should add that David seems to want to exercise the power of the host as well as the privileges of the guest. David, then, it seems to me, is involved in trying to responsibly conquer freedom and is having some difficulty moving from the intoxicating freedom of exercising power with little or no regard for the other's equal human dignity to the sobering freedom of exercising power responsibly-with full regard for the other's equal human dignity. David is, then, like most children, in a state of tension between the person he is at the moment and the person he is striving to become.

But what of Mark's feelings about the picnic? And how far apart are they from David's? At first Mark seems to be a happy guest, to appreciate the food that has been provided, and to discuss the possible choices eagerly with the host. But once the conflict emerges, he is no more willing to be a gracious guest than David is to be a gracious host. Mark immediately sees himself as someone who should be accommodated. And why not? Haven't David and his sister Laura, as members of the hosting family, managed to accommodate their own personal tastes by influencing their mother's purchases at the grocery store? From this perspective, Mark only seeks an equal footing with the other children at the picnic, only seeks to exit the social role of cooperative, grateful guest and demand his equal rights as an individual child. Furthermore, both boys seem determined that the main course of their picnic lunch will be as much as possible like the lunches they eat at home. David wants a hamburger on a round roll, just the way he eats hamburgers at home. And Mark wants a hamburger on a rectangular roll, just the way he eats hamburgers at home. Neither boy, then, is showing much imagination in relation to his choice of a main course. And neither has a very expansive concept of what a picnic is. In other words, both are determined to have their usual preferences satisfied. 
My interpretation, however, does not coincide with the interpretation of the majority of adults at the picnic. Let's pick up the story as the two boys approach their mothers with opposite requests. After hearing David's objections to Mark's request, David's mother acknowledges that the hamburger patties are indeed round, that David did help make them, that, "no," they won't fit very well on rectangular French rolls, and that "yes," the French rolls were in fact brought to use with the hot dogs. But then, in keeping with the spirit of a picnic as a special occasion marked by the relaxed, hospitable, and harmonious atmosphere that can foster openness to possibilities at the moment they arise, she adds that since there are plenty of both kinds of rolls, everyone may have a choice. Taking her cue from her hostess, Mark's mother tells him that he may have a French roll for his hamburger, and she also suggests that they reshape one of the round hamburger patties into a rectangular one that will fit the French roll. Mark marches off in triumph to transform one of the round patties that David has helped to make into a rectangular one, and David proceeds to alternate conspicuous pouting with equally conspicuous attempts to reopen the discussion, probably hoping to change the adult verdict before Mark's rectangular hamburger hits the barbecue grill and roundness is transformed for keeps into rectangularity.

David's unpicnic-like behavior eventually catches the attention of most of the adults, who at first find his behavior an annoyance-a disruption of their adult conversation-but who eventually see in it an opportunity to discuss various theories of upbringing. After a "discreet"4 discussion, in which David and Mark are compared and contrasted in some detail, the majority of adults conclude that David's behavior is essentially dictatorial, antisocial, inhospitable, uncooperative, rigid, and unimaginative whereas Mark's behavior is seen by these same adults as involving an easily accommodatable request that arises from his imaginative perception of a hamburger as something that can be either rectangular or round. Mark becomes a sort of hero of the moment who eats his rectangular hamburger with understandable gusto; David becomes a sort of social outcast who understandably eats next to nothing, and the adults, instead of seeing in David's behavior an appeal for guidance, miss an opportunity to positively influence both children and also may have impressed on David and Mark that one person's freedom must exist at another's expense.

\section{David's Motivation}

The question of whether David's behavior is really dictatorial, antisocial, inhospitable, uncooperative, rigid, and unimaginative is eas- 
ily answered. His behavior is obviously to some degree all of these things-especially dictatorial in its assumption that Mark is a subordinate who must conform to his, David's, wishes. Rather than label David a tyrant and cast him out on the basis of his tyrannical behavior, however, it might be more productive to return to my original question: What makes David such a difficult child? In short, what is his motivation?

I think it is possible to see David as motivated, in part, at least, by a desire to defend his definition of a hamburger as something distinct from a hot dog, as something distinct to some degree on the basis of shape-a shape that David himself has helped impart-as something that has value because it is distinct, as something whose value makes it worthy of respect, and as something that is, at least on the level of concrete survival, most truly respected when it is allowed to retain its individual essence. In other words, David's objection to Mark's choice of rolls could be David's way of asserting, with Don Quixote, that comparisons are odious because they violate the items compared by depriving them of their essences, a deprivation that young children could be especially sensitive to because their own sense of identity is so often tenuous. On this level, David's decision to stand up for the rights of essences (although ill-timed from the adult point of view) could suggest a developing sense of moral courage, the sort of courage it is an adult's responsibility to nurture, and which also sometimes involves a child's selective disobedience or rebellion, which it is to some extent an adult's obligation to endure (live through). The challenge, of course, is to find a way to nurture David's developing sense of moral courage without at the same time permitting him to overstep the rights of others, especially, in this case, the rights of Mark. Above all, that which is good in David's motivation and behavior must be separated out and verified. Otherwise, an opportunity to encourage a child's moral growth will have been lost.

Unfortunately, the adults at the picnic cannot meet the challenge of nurturing David if they have prejudiced themselves against him by focusing on behavior and ignoring motivation. How then can I convince these adults to listen to my argument? How then can I convince them to entertain the possibility that my mention of children, hot dogs, hamburgers, Don Quixote, individual essences, the recognition of true values, and moral courage all in one breath is not necessarily as ludicrous as it sounds? Perhaps I can remind them that adults frequently find themselves in situations parallel to David's. Perhaps if these adults see the David in themselves, they will be more sympathetic to his plight. Perhaps they will offer their hand to the outsider and help him find a place for himself once again within the group. 


\section{The "David" in us all}

Beginning with myself, I can say that although I am an adult who does not care what shape of roll a person chooses for a hamburger, I do experience indignation when people use comparisons that violate the essence of certain words, words that I as a lover of the English language have come to value. For example, when I hear an advertisement for Thunderbird wine or a Thunderbird automobile, I am tempted to shoot a letter off to the manufacturer of these products informing them that the word thunderbird is essentially beautiful in the context of Native American creation mythology and that advertisers violate its essence when they slap it on a label for cheap wine or emblazon it in chrome across the grill of an expensive car. Even observations by my friends and family that my indignation is essentially impotent and idiosyncratic do not sway me from my stance. Arrd in my adult indignation at a comparison I regard as debasing, in my rigid resistance to the violence of metaphor, in my reluctance to attribute through the use of my imagination the power of the Native American thunderbird to a bottle of wine or a car, in my refusal to accommodate the world at large, in my essential willfulness, I am like the child David.

Nor am I alone. If I seek adult company in my selective indignation at comparison-in my right to reject comparisons that debase my sense of value-I have only to look as far as the next room, where my husband sits listening to the blues and grading student art. A sculptor who works in wood and values tools, he has on occasion become indignant when our two children and their friends have attempted to transform a finely crafted spoon gouge or a chisel into a tool for digging in the mud or stirring poster paint.

And from my husband in the living room, I could move into the world outside our home, where I would discover adults everywhere exercising David's prerogative on every imaginable level: I would find a housewife who becomes indignant when some less than sensitive sleeper transforms a strictly decorative bedspread into a quilt for keeping warm; I would find a chef at a fine restaurant who becomes indignant when a diner transforms a masterpiece into a travesty by asking for the ketchup; I would find a neighborhood naturalist who becomes indignant when the recreation department transforms a patch of wood into a tennis court; I would find a secretary who becomes indignant when her boss transforms her into his personal domestic by directing her to scrub and polish his false teeth; I would find a teacher who becomes indignant when a school board transforms her into a second-class citizen by denying her the right to march for civil rights; I would find a husband who becomes indignant when his wife transforms him into a cuckold by engaging in sexual intercourse with his best friend; I would find a surgical nurse who becomes indignant when an anesthesiologist transforms his female patient into an object for sexual gratification by engaging 
her in fellatio while she is under anesthetic; ${ }^{5}$ and I would find a policeman who becomes indignant when a live-in boyfriend transforms a living child into a heap of stinking ash by burning the child alive in the kitchen oven in the presence of his lover, who is also the child's mother, citing as his justification that the child is actually the devil Lucifer in disguise. ${ }^{6}$

\section{Readying Ourselves to be David's Guide}

Now that we adults have had an opportunity to see ourselves as people who routinely deny comparison, as people who exercise our imaginations in the context of our values, now that we have interpreted David's behavior as possibly motivated by something other than mere arbitrary "difficultness," some of us might begin to feel confident enough to respond to David in his particular situatedness, to offer him the guidance that he needs. However, I think such an offer would be premature. I think that before we will be truly ready to offer David anything substantial in the way of guidance, we must first question ourselves about our reactions to atrocity that perpetrators defend by invoking metaphor. We might ask ourselves, for example, some questions about the live-in boyfriend described above who burned his lover's child in his lover's presence. Do we as human beings admire the boyfriend's imaginative solution to the problem of the child as a nuisance? Is the mother to be spared punishment on the grounds that she is an appreciative audience, one that is sensitive and receptive to her boyfriend's creativity? Do we tell the policeman who bags the child's remains that he stifles creativity when he attempts to censor behavior that he knows is criminal?

These questions are absurd, some adults are likely to respond. Absurd and an offense to human dignity, others are likely to chime in. Too obvious to merit a response, still others will object. And yet I ask the questions anyway. Though I want these adults to be right. Though I want each one of us without exception to stand and answer that we do not applaud this boyfriend or this mother, that we weep for them instead, and for the murdered child, and further, that in our weeping we discover our capacity for sorrow in the face of loss and also recognize our obligation (an imperative) to defend the dignity of human beings from those who would debase it through the monstrous perversion of the imaginative power of comparisonthough I want these adults to be right-I cannot bring myself to sentimentalize my view of human nature, to accept as truth these noble human utterances without at least one backward glance at human history.

And so I exercise my memory by recalling a past that includes the Spanish Inquisition and the Salem witch trials, the institution of American slavery, and the continuing apartheid in South Africa, the detention of Japanese Americans in war camps during World War 
II, and the slaughter of the Jews. And by exercising my memory, I make a start toward answering my own question about the boyfriend's burning of the child and the mother's tolerance of his act. I answer from the historical perspective that some of us will stand in protest (deny the boyfriend's right to employ his imagination as he has), some of us will participate in the slaughter (actively support through word or deed, in my opinion from some deeply rooted cowardice, his right to employ his imagination as he has), some of us will watch (affirm his right by being present as innocent bystander or unprotesting audience to his act), and some of us will look the other way (will tolerate his perversion by pretending not to see it, perhaps because we secretly appreciate it or because we haven't the strength of will to protest or because we are simply too busy with our own lives-too self-absorbed). And all of us, I think, to some extent, will make our decision on the basis of our particular situatedness when the atrocity occurs. The mother's situation as a lover could mean that she is more committed to her boyfriend, or to herself, than to her child; and the adults at the picnic could be more committed to bandying superficial explanations of "childishness" than they are to underslanding a given child.

Adults, then, who refuse to attend to history and its relevance to bringing up children in the present day are susceptible to adopting a perspective that is by definition superficial in its deficient involvement with the world as it actually exists and is accessible to them. Such adults must fall short as guides for children, first, because they lead the child toward a less than adult-less than comprehensivepoint of view, and, second, because in their overconfidence they may hold too tightly to their own perspective and so ignore the child's. More specifically, and from a historical perspective, just as the Spanish Jews at Cadiz in 1492 were seen as difficult by the Spanish Monarchy and the Catholic Church, so were the Monarchy and the Church seen as difficult by the Jews; again specifically, and this time from the perspective of the picnic, just as David's behavior is seen as difficult by the majority of adults, so is the adults' behavior seen as difficult by David. Ideally, then, adults who seek to help a child must be able to see themselves as the child sees them, and the adult also must be able to see the child as the child sees himself or herself. In other words, children need adults who understand them, who have the courage and ability to shift perspectives without losing sight of the main goal, which is to guide the child toward the fullest sort of adulthood, to help the child develop a creative tension through which he or she is encouraged to retain an individual essence within the context of the group.

And David, for all his negative behavior, is no exception. Hands in pockets, eyes downcast, circling an oak tree, kicking at the grass, not speaking when spoken to, muttering to himself, David is an obviously miserable child. So miserable, in fact, that I am tempted to 
play God-lots of adults do it-and resurrect the Rumanian born French sculptor, Constantin Brancusi, from the dead, on the condition-as God I could be as conditional as I like-that he appear to the adults at the picnic in his maturity, that he appear, in other words, as an aging adult artist wearing his long white robe and sporting his long white beard, an artist covered from head to foot with the fine white dust of carved Carrara marble, an artist flanked by his two white dogs and armed with the white washbasin into which he pours, from the bottle he has brought, the white milk with which he nourishes them. ${ }^{7}$ And when he stands before the adults at the picnic, I would ask him, graciously, of course, because, though God, I would also be his host and he my guest, to tell the adults at the picnic what he once told his young apprentice Isamu Noguchi: "Who is no longer a child is no longer an artist,"8 were Brancusi's words. And although what Brancusi really meant, only Brancusi knows for sure, I would be just impertinent enough in my superhuman role to speculate that, for Brancusi, the act of creation originates in the artist's ability to reach back through time and space at will and grasp the essence of beginnings, the essence of potentiality and possibility; in other words, the essence of the child. "Who is no longer a child is no longer an artist," is a statement, then, that could apply as readily to the teacher as to the artist, if by teacher is meant an adult who is able to meet the child in his or her distinct and specific situatedness and guide the child gradually through time and space from a sort of infantile chaos to a new and orderly adult reality.

\section{Guiding David Through his Difficultness}

But as a human being, and no God, I lack the power of resurrection, and so seek a human solution to the crisis by calling on the help of a fellow human being, David's father, who, instead of encountering the adults, encounters David in his loneliness and takes him for a walk along the river bank. They talk about the shape of things, about what makes a hamburger really a hamburger, about what makes a hot dog really a hot dog, about what it means to be a host and what it means to be a guest, about the thoughtlessness of some adults, about how much it hurts when friends do not appreciate our efforts, and, eventually, about the rights of Mark. David's father, then, encourages David to see the conflict with Mark in its totality, and then helps him to understand, as best he can, the conflict in its various parts, finally helping his son to resynthesize or reconstitute the conflict into a more harmonious, less discordant lived-experience than the experience as first lived through by David. Intervening both acceptively and correctively, David's father has helped him separate out that which is good in his experience and let go the rest. When David returns to the picnic table, he sits down with Mark, accepts from his own mother-the very same woman who betrayed him earlier by ruling in favor of Mark-a piece of chocolate cake and peels the frosting off. David is once again an individual child capable of existing in a group. 
My final task in coming to grips with David's difficultness is to face a second time the fact of Don Quixote, but this time I must see him in the light of Constantin Brancusi. Can Don Quixote's belief that comparisons are odious stand beside the comparison implicit in Brancusi's observation that "Who is no longer a child is no longer an artist?" And what of all the comparisons I myself have made throughout my argument? In my first sentence I compared difficult, disagreeable children to Don Quixote. Later, in a footnote, I compared the anesthesiologist Miofsky to the adults at the picnic. And just now I have compared a teacher to an artist. Am I to be denied these comparisons by some fictional knight who exists between the covers of a book written in Spain in 1604? Must I tolerate a perspective so far removed from my own here and now, especially one that seems not quite to fit my argument, not in its beginnings, perhaps, but as it has developed?

"Don Quixote does not belong; throw Don Quixote out," shouts some true believer in consistency who would attempt to help me solve my problem. And yet I like my aging knight much too much to cast him out. Besides, there is no need. For the man who is referred to by his neighbors as "plain Señor Quixana," a man nearing 50 who eats his meals alone and spends his evenings reading romance, transforms himself, through the power of comparison, into Don Quixote de la Mancha, the Knight of the Sad Countenance. ${ }^{9}$ In other words, although Don Quixote denounces comparisons as odious, he at the same time lives metaphorically. In my opinion, he possesses the artist's imagination: He simultaneously grasps two seemingly contradictory perspectives; he manages to maintain artistic tension without feeling compelled to reach out toward the comfort of consistency or resolution. ${ }^{10}$

I would be a fool to cast Don Quixote out. Don Quixote is my argument. (And yes, I know that I have just indulged in yet another metaphor.) He has come to know, through lived-experience, that comparisons are both odious and sublime, that comparisons have the power to overwhelm as well as the power to actualize. Instead of an aging man who eats alone and reads romance, Don Quixote becomes a seeker of adventure in the world at large. And I would like to add, lest there be some among us who are as yet reluctant to perceive love as adventure, that Don Quixote seeks love as much as anything. Through the power of comparison, Don Quixote gives direction to his individual essence. And we as adults in charge of children would be wise to acknowledge his accomplishment. For if we lose our sense of direction, if we define our world only in relation to ourselves, if we cannot from our subjective vantage point sustain the tension between the child's point of view and the adult's, if we define the child as other than he or she actually is, if we try to love the child as that other, then we indulge in the odious sort of comparison that 
deprives a child of the right to be himself or herself. In other words, when we as adults lose our way, we know not where to lead the child. And the child, sensing that his or her guide is lost, begins inevitably to cry. Impatient in the face of crying we cannot quiet, deaf to it as a signal of distress, as a cry that says, "I love your adultness. I want you not to be lost. I need you to help me find my way." We as adults label our children difficult and cast them out when we should most embrace them as our touchstones. As much as anything, it is an adult failure of imagination that is the source of David's difficulty. And it is this same adult failure that helps us understand the boyfriend's burning of the living child. We as human beings can make comparisons that truly illuminate only if we have the imagination to grasp individual essences. This is a bottom line for me, and it is the reason I would never push a child too fast toward flexibility, even flexibility that is creative, and the reason I would have to be convinced by someone I have yet to meet of the value of flexibility that is facile. It is also the reason I find myself in sympathy not only with the child Mark, but also with the child David.

\section{Notes}

1. My conversations with other adults about child-crises have made clear to me that many people equate a child-crisis with a childish crisis, which is why I want to take a minute to consider the carelessness involved in applying the word childish, in its negative connotations, to children, when, according to the dictionary, childish, in its negative connotations, is more appropriately applied to adults who are behaving immaturely. I guess my real concern is that in our everyday dealings with children we seem more and more to define behavior that arises naturally from what it means to be a child as "childish," and then, once we have defined natural behavior negatively, we feel justified in becoming impatient with it. It seems to me that in this instance, our careless use of the language is closely tied to our careless approach to child rearing. If we continue to abuse the word childish, its abusive definition may eventually become standard and our language will then of ficially help us perpetuate our careless approach to children.

2. Langveld, M.J. (1958). Disintegration and reintegration of "pedagogy." International Review of Education, 4,54 .

3. The conversation is reproduced from my observation of the boys at the picnic.

4. Although most of us have probably on occasion indulged in the careless labeling of children (I certainly know that I have), I do not believe there is any such thing as a "discreet" conversation in the context described in the text. In my experience, children hear, attend, listen, reflect, and remember with more depth than adults often give them credit for. Why we adults sometimes discuss children in the children's presence, as if the children do not exist, seems to me easily explained on the grounds that the children we discuss do not exist for us in any essential sense, at least not for the duration of the conversation.

5. The anesthesiologist, Dr. William Miofsky (he pleaded no contest to three felony charges in Sacramento, California, in 1979), who indulged in 
"discreet" fellatio, and the adults at the picnic, who indulged in discreet conversation, share the dubious distinction of affording people in their careless protection than human dignity deserves. One argument I sometimes hear adults make in defense of discreet talk about children in front of children is that they are for all intents and purposes oblivious of the talk. "Oh, they're too busy playing to pay any attention to what we're saying," or "Oh, I don't think they even hear us, and if they do, it won't really matter, because they'll have forgotten it all by dinner time," are comments typical to this defense. Interestingly enough, a similar argument was made by various members of the public in response to the Miofsky scandal: "I don't think what he did was so bad, really. I mean, how could patients under anesthetic suffer any damage in the first place?" was a not infrequent comment. However, David's behavior suggests the weakness of this argument in the context of the picnic, just as the emotional trauma testified to by Miofsky's patients (as well as by recent research into the degree of consciousness of patients under anesthetic) contradicts the validity of this argument in the context of the operating room.

6. Examples in the paragraph are drawn from my experiences, the experiences of family, friends, and acquaintances, or from news sources and books. Specifically, the story of the child's burning is from the The Sacramento Bee (Oct 29, 1984), p. A3.

7. The description of Brancusi is derived from a photograph and comments in Noguchi, I. (August, 1976). Noguchi on Brancusi. Craft Horizons, 26-29.

8. Noguchi, p. 29.

9. Rather than as a ridiculous idealist, an anachronism, or a laughingstock, and unlike many readers, I see Don Quixote as essentially heroic. For an impassioned discussion of him as a man who fought not for ideas or idealism but for the spirit, see Miguel De Unamuno (1954). Tragic Sense of Life. New York: Dover, pp. 297-330.

10. My view of artistic imagination is based on John Keats much discussed reference to negative capability in his letter to George and Thomas Keats. See Keats' Selected Poems and Letters. Riverside, MA: The Riverside Press, 1959, p. 261.

\section{References}

Straus, E. (1963). The primary world of senses. New York: The Free Press of Glençoe. 